\title{
Insulin-Like Growth Factors and Insulin-Like Growth Factor Binding Proteins in Porcine Serum and Milk throughout Lactation
}

\author{
SHARON M. DONOVAN, LESLIE KLIS MCNEIL, RAFAEL JIMÉNEZ-FLORES, \\ AND JACK ODLE \\ Division of Foods and Nutrition, Department of Food Science and Department of Animal \\ Sciences, University of Illinois, Urbana, Illinois 61801
}

\section{ABSTRACT}

IGF-I, IGF-II, and IGF binding proteins (IGFBP) were characterized in porcine serum, colostrum, and milk on $d$ 1-28 postpartum. IGF-I and -II were measured by heterologous RIA. Serum IGFBP were characterized by Western ligand blotting and milk IGF binding activity by [ $\left.{ }^{125} \mathrm{I}\right]-\mathrm{IGF}$ binding assay. IGF-II accounted for $70-85 \%$ of serum IGF and rose 2-fold between $d 1$ and $d 28$. Serum IGF-I was unaffected by duration of lactation. Milk IGF-II concentrations were higher than IGF-I concentrations on $d$ 1-7 postpartum. After d 10, milk IGF-I and IGF-II contents were not significantly different. Serum contained IGFBP with $M_{r}$ of $43,39,34,28$, and $24 \mathrm{kD}$. Over the course of lactation, the $43-$ and $39-\mathrm{kD}$ bands increased, the $24-\mathrm{kD}$ band decreased, and the 34- and 28-kD bands were unchanged. Milk IGF binding activity increased between $\mathrm{d} 1$ $(28 \%)$ and $d 3(44 \%)$, then declined until d $28(7 \%)$. Serum

IGF-I and IGF-II have been found in the milk of all species studied (1-5). IGF seem to be intricately involved in successful lactation, as evidenced by their roles in stimulating mammary growth (6), differentiation, and galactopoiesis (7). In addition to supporting lactation, milk IGF have been postulated to exert a direct trophic effect within the gastrointestinal tract of the suckling neonate $(8,9)$. Very little IGF is found in the free state in physiologic fluids; rather, IGF-I and -II in serum and other extracellular fluids are associated with six genetically distinct but structurally related IGFBP (IGFBP-1 through IGFBP-6) (10). Several IGFBP are posttranslationally modified by serine phosphorylation and $\mathrm{N}$ - or O-linked glycosylation. Posttranslational modifications alter the net charge of the IGFBP and may also affect the affinity of the IGFBP for IGF (10). IGFBP-3, the predominant serum IGFBP, circulates as a $150-\mathrm{kD}$ complex that is

Received September 7, 1993; accepted March 7, 1994.

Correspondence: Dr. Sharon Donovan, Division of Foods and Nutrition, 386 Bevier Hall, 905 S. Goodwin Ave., University of Illinois, Urbana, IL 61801. Supported by NIH Grant RO1 HD-29264 from the NICHD. and milk were separated by isoelectric focusing into 20 fractions, across a gradient from $\mathrm{pH} 3$ to 10 , that were screened for IGFBP by Western ligand blotting. Milk contained six IGFBP of similar $M_{r}$ as serum IGFBP; however, the relative amounts of the IGFBP and their apparent isoelectric points differed. In conclusion, porcine milk contains both IGF-I and -II, with IGF-II predominating. Several IGFBP with similar $\mathbf{M}_{r}$ as those found in serum are present in milk. IGF peptide concentrations were highest in prepartum secretions and colostrum, whereas IGF binding activity peaked on d 4 of lactation. (Pediatr Res 36: 159-168, 1994)

\section{Abbreviations}

IGFBP, insulin-like growth factor binding protein TBS, Tris-buffered saline

impermeable to vascular epithelium (11), thus increasing the half-life of circulating IGF (12). In addition, in vitro work has demonstrated that IGFBP modulate the interaction of IGF with its cellular receptors (13). Several IGFBP (IGFBP-3, -2, -1, and -4) have been reported in human, rat, goat, pig, and cow milk (1-5). The molecular forms of the IGFBP present in milk seem to be species specific; however, IGFBP-2 has been consistently reported in milk. Whether IGFBP in milk protect milkborne IGF from degradation or modulate IGF action within the neonatal gastrointestinal tract is unknown.

IGF-I and IGF binding activity have been reported in porcine milk $(3,9)$; however, the presence of IGF-II and characterization of the specific IGFBP contained in pig milk had not been investigated. Therefore, the goal of the current study was to establish normative porcine colostrum and milk IGF-I and -II concentrations as part of our research into the role of IGF in neonatal intestinal development. In addition, determining the IGFBP profile in milk is essential to understanding what role IGFBP may play in modulating the action of IGF in milk. 


\section{METHODS}

IGF. Recombinant human IGF-I and IGF-II were generously provided by Genentech (So. San Francisco, CA) and Eli Lilly (Indianapolis, IN), respectively. $3-\left[{ }^{125}\right.$ I]iodotyrosyl IGF-I $\left[\right.$ thr $\left.^{54}\right]$ and 3-[ ${ }^{125}$ I] iodotyrosyl IGF-II were purchased from Amersham, Inc. (Arlington Heights, IL).

Biologic samples. Milk and serum samples were collected between 0700 and $0900 \mathrm{~h}$ on $\mathrm{d} 1-4,7,10,14,18,21$, 24 , and 28 of lactation from Yorkshire-Duroc crossbred sows $(n=4)$ housed at the Swine Research Center on the University of Illinois campus. Because parity (5) affects milk IGF concentrations, we limited our study to secondparity sows. Because of early weaning, one sow was not sampled on d 28. To collect samples, piglets were removed from the pen and sows received injections of 200 $\mathrm{mU}$ of oxytocin; milk was collected by manual expression within 15 to $30 \mathrm{~min}$. Sows were then restrained, and $5 \mathrm{~mL}$ of blood were drawn from an ear vein. Serum was obtained by allowing blood to clot for approximately 30 $\min$ on ice, followed by centrifugation at $12000 \times g$ for $15 \mathrm{~min}$. To investigate prepartum and postweaning changes in milk and serum IGF and IGFBP, prepartum mammary secretions were collected from sows $(n=4)$ $\leq 12 \mathrm{~h}$ before farrowing, and blood samples were collected from sows $(n=4) 6$ d postweaning. Samples were stored at $-70^{\circ} \mathrm{C}$. Animal procedures were approved by the University of Illinois Laboratory Animal Care Committee.

Milk protein quantitation. Protein content was determined using a modified Lowry protein assay (14) with BSA (Sigma Chemical Co., St. Louis, MO) as the protein standard. Prepartum mammary secretions were diluted $1: 300$ and colostrum and milk samples $1: 100$ before assay.

Column chromatography. To dissociate the IGF from the IGFBP, serum and milk samples $(500 \mu \mathrm{L})$ were chromatographed in $0.2 \mathrm{M}$ formic acid on a $0.9 \times 100-\mathrm{cm}$ column containing Sephadex G-50 (fine) (Pharmacia Fine Chemicals, Piscataway, NJ) (15). Serum was applied directly to the column, and only the IGF peptide fraction (46 to $71 \mathrm{~mL}$ ) was collected. Milk proteins were precipitated before application to the column by the addition of $500 \mu \mathrm{L}$ of $0.2 \mathrm{M}$ formic acid and centrifugation at 12000 $\times g$ for $1 \mathrm{~min}$. The entire resulting supernatant was then applied to the column. No IGF or IGF binding activity was detected in the protein pellet by RIA or [ ${ }^{125}$ I] IGF-I charcoal binding assay, respectively. Both the milk IGFBP fraction $(28-45 \mathrm{~mL})$ and the milk IGF peptide fraction were collected. Eluent containing the IGFBP was collected into 50-mL tubes, adjusted to a final concentration of $200 \mathrm{mM}$ Tris, $0.002 \%$ sodium azide, $\mathrm{pH} 7.4$, and stored at $4^{\circ} \mathrm{C}$ until use in the charcoal binding assay. Fractions containing the IGF peptide were collected in 50 -mL tubes containing $0.25 \mathrm{~mL}$ of IGF RIA buffer $(0.03$ $\mathrm{M}$ sodium phosphate, $0.25 \% \mathrm{BSA}, 0.02 \%$ sodium azide, $\mathrm{pH} 7.5$ ) and were frozen and lyophilized (Flex-Dry, FTS Systems, Stone Ridge, NY) for IGF-I and -II RIA as described below. Recovery of IGF from the column, determined by spiking several milk samples with 100 $\mathrm{ng} / \mathrm{mL}$ IGF-I, was $>90 \%$.

IGF-I and -II RIA. Lyophilized IGF peptide fractions were resolubilized in RIA buffer without added BSA. Both IGF-I and -II were measured using heterologous RIA; however, acid-chromatographed pig serum and milk samples gave parallel displacement curves to the human recombinant IGF-I and -II standards (data not shown). IGF-I content was measured using [ ${ }^{125}$ I] human IGF-I as radioligand and a polyclonal anti-somatomedinC/IGF-I antibody generated by Drs. Underwood and Van Wyk, University of North Carolina at Chapel Hill and distributed through the National Hormone and Pituitary Program. The lowest level of detection for the assay is 25 $\mathrm{pg} /$ tube. The following dilution factors were used: serum and prepartum mammary secretions, 1:100; colostrum (lactation d 1-4), 1:50; and milk, 1:10. Interassay and intraassay coefficients of variation for the IGF-I assay were $7 \%$ and $4 \%$, respectively. IGF-II content was measured by RIA using recombinant $\left[{ }^{125} \mathrm{I}\right] \mathrm{IGF}-\mathrm{II}$ and an $\mathrm{MAb}$ against rat IGF-II (Mitsubishi International Corp., Philadelphia, PA). The lowest level of detection for the assay is $50 \mathrm{pg} /$ tube. The following dilutions were used: serum and prepartum mammary secretions, 1:50; colostrum (lactation d 1-4), 1:20; and milk, 1:4. Interassay and intraassay coefficients of variation for the IGF-II assay were $8 \%$ and $6 \%$, respectively.

SDS-PAGE and Western ligand blot analysis of serum IGFBP. Molecular forms of IGFBP were characterized by Western ligand blotting using the method of Hossenlopp et al. (16) as previously described $(1,2)$. Serum samples $(4 \mu \mathrm{L})$ were mixed with Laemmli sample buffer (17) and heated at $100^{\circ} \mathrm{C}$ for $5 \mathrm{~min}$. Samples were separated on SDS-PAGE gels consisting of $4 \%$ stacking gels and $12 \%$ separating gels. Gels were run at $70 \mathrm{~V}$ overnight at $4^{\circ} \mathrm{C}$. Size-separated proteins were electrotransferred to nitrocellulose $(0.45 \mu \mathrm{m}$, Micro Separations Inc., Westborough, MA) using a Labconco semidry transfer apparatus (Labconco Corp., Kansas City, MO). Nitrocellulose membranes were sequentially incubated with TBS $(0.15 \mathrm{M}$ sodium chloride, $0.01 \mathrm{M}$ Tris- $\mathrm{HCl})$ containing $3 \%$ Nonidet P-40 (Tergitol NP-40, Sigma), TBS containing $1 \%$ BSA, and TBS containing $0.1 \%$ Tween 20 at $4^{\circ} \mathrm{C}$. Membranes were then incubated overnight at $4^{\circ} \mathrm{C}$ with $0.5 \mu \mathrm{Ci}$ of $\left[{ }^{125} \mathrm{I}\right] \mathrm{IGF}-\mathrm{I}$, washed with TBS, and air dried. The IGFBP were visualized by exposure to Kodak $\mathrm{X}$-Omat AR film (Rochester, NY) for $7 \mathrm{~d}$ at $-70^{\circ} \mathrm{C}$. The relative intensities of the IGFBP bands on the autoradiographs were determined using the FotoAnalyst II Imager System and Collage software (Fotodyne Incorporated, New Berlin, WI).

Rotofor separation of serum and milk IGFBP. Pig serum and milk samples were separated by solution isoelectric focusing on a Rotofor apparatus (Bio-Rad, Richmond, CA). This method was used for two reasons. First, the high protein content of porcine milk resulted in poor resolution of the molecular forms of the IGFBP by West- 
ern ligand blotting. Using the Rotofor apparatus, milk IGFBP focused at a higher $\mathrm{pH}$ than casein allowing for clearer resolution of milk IGFBP. Second, this method also allowed for determination of the approximate $\mathrm{pI}$ of IGFBP in porcine serum and milk. The Rotofor apparatus consists of a cylindrical focusing chamber with buffer capacity of $55 \mathrm{~mL}$. The focusing chamber is separated into 20 discrete compartments by insertion of a molded polyethylene membrane core into the chamber. The entire focusing chamber is rotated at $1 \mathrm{rpm}$, which enhances sample separation. Serum samples $(0.5$ $\mathrm{mL}$ ) were separated in $50 \mathrm{~mL}$ of buffer containing $2 \%$ glycerol, 5\% Triton $\mathrm{X}-100$, and $1 \%$ ampholytes (pH range of 3-10) (Bio-Rad). Defatted milk samples (1.0 $\mathrm{mL}$ ) were separated using the same buffer with the addition of $6 \mathrm{M}$ urea to enhance solubility of casein micelles by decreasing hydrophobic interactions. Focusing was carried out for approximately $4 \mathrm{~h}$ at $12 \mathrm{~W}$ constant power. Twenty fractions were collected and their $\mathrm{pH}$ recorded. The fractions were placed into dialysis tubing (10 000 molecular weight cutoff; Spectrapor, Spectrum Medical Industries, Los Angeles, CA) and dialyzed overnight against PBS to remove the ampholytes. The fractions were lyophilized and resolubilized in $300 \mu \mathrm{L}$ of $50 \mathrm{mM}$ Tris buffer ( $\mathrm{pH} 7.4$ ), and $30 \mu \mathrm{L}$ were used for SDS-PAGE. One gel was stained with Coomassie blue to show the protein separation, and the second gel was Western ligand blotted as described above.

Milk IGF binding activity. Milk IGFBP activity was measured throughout lactation using a modification of the charcoal binding assay previously described (1). Duplicate samples $(100 \mu \mathrm{L})$ of the $\mathrm{pH}$-adjusted Sephadex G-50 IGFBP fractions (1:40 sample dilution) were incubated with $\left.{ }^{125} \mathrm{I}\right] \mathrm{IGF}-\mathrm{I}(\approx 0.005 \mu \mathrm{Ci})$ in binding buffer $(0.05 \mathrm{M}$ Tris- $\mathrm{HCl}, \mathrm{pH} 7.4,0.02 \% \mathrm{BSA}$ ) in a $1.5-\mathrm{mL}$ microfuge tube. After incubation for $2 \mathrm{~h}$ at room temperature, 1.0 $\mathrm{mL}$ of activated charcoal $(0.5 \%$, in TBS $+0.02 \%$ BSA, $\mathrm{pH}$ 7.4) containing protamine sulfate $(0.2 \mathrm{mg} / \mathrm{mL})$ was added. Tubes were incubated for $30 \mathrm{~min}$ at $4^{\circ} \mathrm{C}$, then centrifuged at $12000 \times g$ for $5 \mathrm{~min}$ to precipitate the unbound [25:]IGF-l. The supernatants containing the bound [ ${ }^{125}$ I]IGF-I were counted for 1 min (Cobra AutoGamma Counter, Packard Instruments, Downers Grove, IL). The percent bound was calculated by dividing $\mathrm{cpm}$ recovered in the supernatants minus the nonspecific binding $(7 \%)$ by the total counts added (approximately $10000 \mathrm{cpm})$.

Statistical analysis. Statistical analyses were performed using the SAS program (SAS Institute, Inc., Cary, NC). Data from the longitudinal study (d 1-28 of lactation) were compared using a repeated-measures analysis of variance and the general linear models procedure within SAS and were considered to be statistically significant at $p \leq 0.05$ by Tukey's test. The protein content, IGF-I and -II content, and IGF binding activity of prepartum secretions were compared with d-1 postpartum samples using $t$ test. Serum IGF-I and -II concentrations of 6-d postweaning sows were compared with lactating sows using $t$ test. Pearson's correlations were determined between serum and milk IGF-I and -II, serum IGF and IGFBP, and milk IGF and IGF binding activity.

\section{RESULTS}

Milk protein content. Milk protein content (mean $\pm \mathrm{SD}$ ) decreased by half between $\mathrm{d} 1$ and $\mathrm{d} 2$ postpartum ( $154 \pm$ 4 to $75 \pm 16 \mathrm{~g} / \mathrm{L}$ ) (Table 1). Milk protein content continued to decline until d 10 of lactation, after which concentrations were maintained at approximately $40 \mathrm{~g} / \mathrm{L}$, which is within the range of porcine milk protein content previously reported $(3,9)$. The protein content of prepartum mammary secretions $(214 \pm 17 \mathrm{~g} / \mathrm{L})$ was $40 \%$ higher than that of $\mathrm{d}-1$ colostrum $(p \leq 0.05)$.

Milk IGF-I and -II. Milk IGF-I and -II concentrations throughout lactation are presented in Table 1. The IGF-I $(18 \pm 2.9 \mathrm{nM})$ and $-\mathrm{II}(39 \pm 8.6 \mathrm{nM})$ contents of prepartum secretions were approximately twice those found in d- 1 colostrum $(9.4 \pm 1.4$ and $22 \pm 2.4 \mathrm{nM}$, respectively). Both IGF-I and -II declined as lactation progressed, with a 4 - to 5-fold drop between $\mathrm{d} 1$ and d 2 postpartum $(p \leq$ $0.05)$. IGF-II concentrations in prepartum secretions and

Table 1. Milk protein and IGF concentrations throughout lactation*

\begin{tabular}{|c|c|c|c|c|c|}
\hline \multirow[b]{2}{*}{ Day } & \multirow{2}{*}{$\begin{array}{c}\text { Protein } \\
(\mathrm{g} / \mathrm{L})\end{array}$} & \multicolumn{2}{|c|}{ IGF-I } & \multicolumn{2}{|c|}{ IGF-II } \\
\hline & & $\mu \mathrm{g} / \mathrm{L}$ & $\mathrm{nM}$ & $\mu \mathrm{g} / \mathrm{L}$ & $\mathrm{nM}$ \\
\hline Prepartum & $214 \pm 17 \dagger$ & $136 \pm 22.6$ & $18 \pm 2.9+$ & $291 \pm 64.5$ & $39 \pm 8.6 \dagger$ \\
\hline 1 & $1.54 \pm 4 .()^{4}$ & $72 \pm 10.7$ & $9 \pm 1.4^{\prime \prime}$ & $165 \pm 18.0$ & $22 \pm 2.4^{a}$ \\
\hline 2 & $75 \pm 16^{h}$ & $31 \pm 17.1$ & $4.0 \pm 2.2^{b}$ & $77 \pm 49.7$ & $10 \pm 4.7^{b}$ \\
\hline 3 & $73 \pm 11^{b}$ & $27 \pm 9.3$ & $3.6 \pm 1.2^{h}$ & $50 \pm 14.1$ & $6.6 \pm 1.9$ \\
\hline 4 & $66 \pm 9.4^{\prime}$ & $26 \pm 9.4$ & $3.4 \pm 1.2^{h}$ & $38 \pm 4.9$ & $5.0 \pm 0.7^{c, d}$ \\
\hline 7 & $55 \pm 1.5^{\circ}$ & $11 \pm 1.3$ & $1.4 \pm 0.2^{x}$ & $29 \pm 8.1$ & $3.8 \pm 1.1^{d}$ \\
\hline 10 & $4.5 \pm 7.1^{\circ}$ & $14 \pm 1.9$ & $1.8 \pm 0.3^{\circ}$ & $18 \pm 3.8$ & $2.4 \pm 0.5^{d}$ \\
\hline 14 & $39 \pm 7.2^{\prime}$ & $12 \pm 2.3$ & $1.6 \pm 0.3^{\circ}$ & $16 \pm 3.6$ & $2.1 \pm 0.5^{\prime \prime}$ \\
\hline 18 & $40 \pm 10$ & $12 \pm 2.0$ & $1.6 \pm 0.3^{3}$ & $16 \pm 1.0$ & $2.1 \pm 0.1^{d}$ \\
\hline 21 & $42 \pm 10$ & $10 \pm 1.3$ & $1.3 \pm 0.2$ & $15 \pm 1.4$ & $2.1 \pm 0.2^{d d}$ \\
\hline 24 & $41 \pm 6.1^{\circ}$ & $11 \pm 2.7$ & $1.4 \pm 0.4$ & $14 \pm 4.3$ & $1.8 \pm 0.6^{t}$ \\
\hline 28 & $40 \pm 5.3^{\circ}$ & $10 \pm 1.9$ & $1.3 \pm 0.2^{c}$ & $11 \pm 1.3$ & $1.5 \pm 0.2^{d}$ \\
\hline
\end{tabular}

* Mean \pm SD. Prepartum, $n=4 ; \mathrm{d} 1-24, n=4 ; \mathrm{d} 28, n=3$. Different letter superscripts indicate differences at $p<0.05$.

$\dagger$ Significantly greater than $d-1$ postpartum samples, $p<0 .(0) 1$. 
in colostrum through $\mathrm{d} 7$ postpartum were approximately 2 -fold higher than IGF-I concentrations. After $d 10$ postpartum, IGF-I and -II concentrations were similar, averaging between 1 and $3 \mathrm{nM}(10-20 \mu \mathrm{g} / \mathrm{L})$. Serum IGF-II concentrations were inversely correlated with milk IGF-II $(r=-0.46, p=0.002)$, whereas no relationship was observed between serum and milk IGF-I $(r=0.02, p$ $=0.91$ ).

Serum IGF-I and -II. Serum IGF-I and -II concentrations throughout lactation are contained in Table 2. IGF-II is the predominant serum IGF in the sow, accounting for $70-85 \%$ of the total serum IGF. Serum IGF-II concentrations rose progressively over the course of lactation from $31 \pm 7.8 \mathrm{nM}(231 \pm 58 \mu \mathrm{g} / \mathrm{L})$ on $\mathrm{d} 1$ to $68 \pm 15 \mathrm{nM}(511 \pm 110 \mu \mathrm{g} / \mathrm{L})$ by d 28 postpartum. IGF-II concentrations were significantly elevated over $d-1$ concentrations by $\mathrm{d} 10$ postpartum. Serum IGF-I concentrations ranged between 7.0 and $18 \mathrm{nM}(50$ and $140 \mu \mathrm{g} / \mathrm{L})$ and were not affected by the stage of lactation. Serum IGF-I and -II concentrations of sows $6 \mathrm{~d}$ postweaning (nonpregnant, nonlactating sows) were significantly higher than those on d 28 postpartum $(p>0.05)$.

Western ligand blot of serum IGFBP throughout lactation. Autoradiographs of serum IGFBP profiles for two sows throughout lactation are shown in Figure 1. Sow serum contained IGFBP with apparent $M_{r}$ of $43,39,34,28$, and $24 \mathrm{kD}$. The 43-, 39-, 34-, and 28-kD bands have been immunologically identified $(18,19)$. The $43-$ and $39-\mathrm{kD}$ bands are glycosylated variants of porcine IGFBP-3 (18); the 34-kD band is IGFBP-2, a nonglycosylated IGFBP $(18,19)$; and the 28-kD band is IGFBP-1 (19). The 24-kD band has not been immunologically identified in porcine serum but may be IGFBP-4, on the basis of its molecular weight, which is similar to that of rat and human IGFBP-4 (10). IGFBP-4 can also be found as a 28-kD glycosylated protein $(20)$, potentially contributing to the $28-\mathrm{kD}$ band in porcine serum.

Densitometric analysis of the relative intensities of the serum IGFBP throughout lactation for all four sows is shown in Table 3. To correct for variation between sows,

Table 2. Serum IGF concentrations throughout lactation*

\begin{tabular}{rcclll}
\hline & \multicolumn{2}{c}{ IGF-I } & & \multicolumn{2}{c}{ IGF-II } \\
\cline { 2 - 3 } \cline { 5 - 6 } Day & $\mu \mathrm{g} / \mathrm{L}$ & $\mathrm{nM}$ & & $\mu \mathrm{g} / \mathrm{L}$ & $\mathrm{nM}$ \\
\hline 1 & $57 \pm 20$ & $7.4 \pm 2.7^{a}$ & & $231 \pm 58$ & $31.0 \pm 7.8^{a}$ \\
2 & $72 \pm 25$ & $9.4 \pm 3.3^{a b}$ & & $282 \pm 84$ & $37.9 \pm 11.2^{a}$ \\
3 & $87 \pm 35$ & $11.4 \pm 4.6^{b}$ & & $305 \pm 85$ & $40.8 \pm 11.5^{a}$ \\
4 & $136 \pm 37$ & $17.8 \pm 4.9^{c}$ & & $312 \pm 120$ & $41.7 \pm 7.1^{a}$ \\
7 & $60 \pm 16$ & $7.8 \pm 2.0^{a}$ & & $286 \pm 63$ & $38.2 \pm 8.7^{a}$ \\
10 & $60 \pm 14$ & $7.8 \pm 1.9^{a}$ & & $387 \pm 103$ & $51.8 \pm 13.8^{b}$ \\
14 & $107 \pm 44$ & $14.0 \pm 5.7^{d}$ & & $407 \pm 106$ & $54.5 \pm 14.1^{b}$ \\
18 & $50 \pm 12$ & $6.5 \pm 1.6^{a}$ & & $415 \pm 81$ & $55.5 \pm 10.8^{h}$ \\
21 & $51 \pm 6.8$ & $6.6 \pm 0.9^{a}$ & & $462 \pm 122$ & $61.9 \pm 16.3^{b c}$ \\
24 & $57 \pm 9.1$ & $7.4 \pm 1.2^{a b}$ & & $492 \pm 17$ & $65.8 \pm 2.2^{c}$ \\
28 & $53 \pm 3.6$ & $7.0 \pm 0.5^{a b}$ & & $511 \pm 110$ & $68.4 \pm 14.7^{c}$ \\
NPNL & $72 \pm 11$ & $9.4 \pm 1.4^{b}$ & $546 \pm 57$ & $73 \pm 7.6^{c}$ \\
\hline
\end{tabular}

* Mean \pm SD. d 1-24, $n=4 ;$ d 28, $n=3$. Different letter superscripts indicate differences at $p \leq 0.05$. NPNL, nonpregnant, nonlactating sows, $6 \mathrm{~d}$ postweaning $(n=4)$.
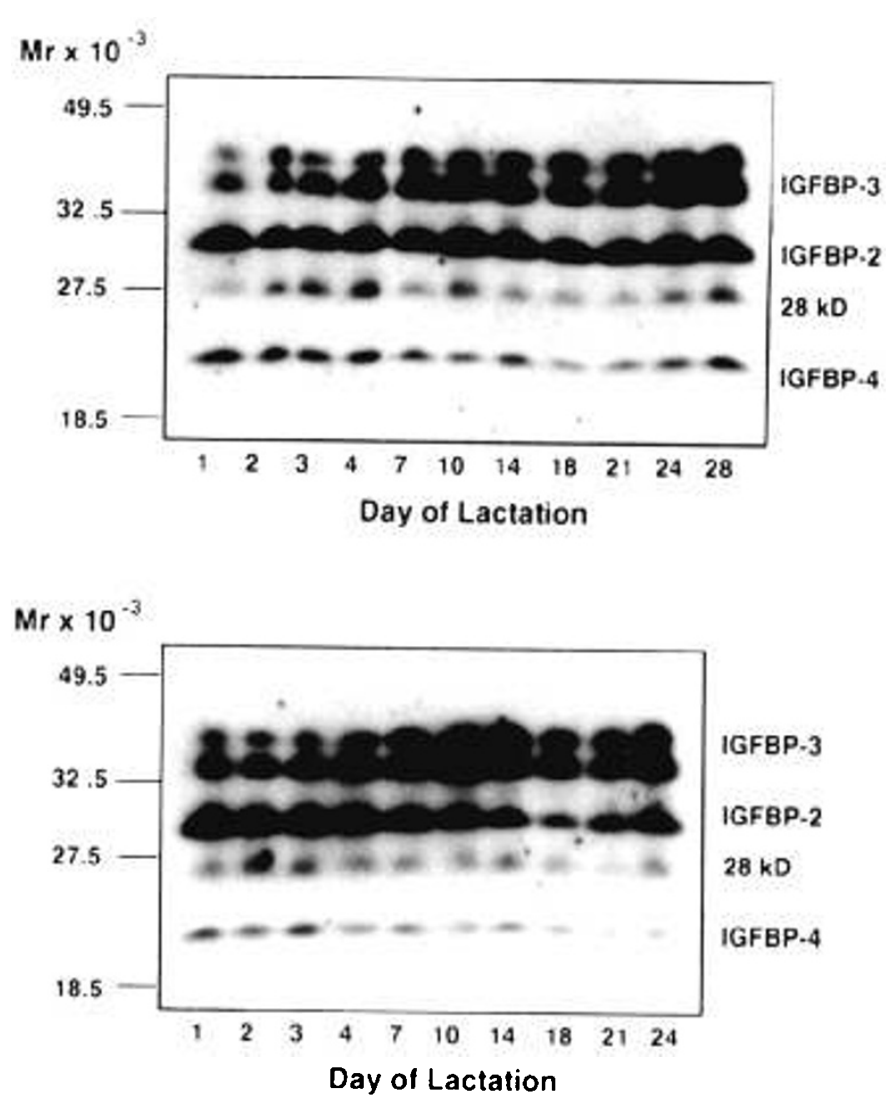

Figure 1. Representative serum IGFBP profiles throughout lactation. Autoradiographs of Western ligand blots of serum IGFBP profile of two sows throughout lactation. Serum samples $(4 \mu \mathrm{L})$ were separated by SDS-PAGE, Western ligand blotted using [ $\left.{ }^{125} \mathrm{I}\right] \mathrm{IGF}-1$, and exposed to film for $7 \mathrm{~d}$. Bands with apparent $M_{r}$ of $43,3934,28$, and $24 \mathrm{kD}$ were visualized. The intensity of the $43-$ and $39-\mathrm{kD}$ bands tended to increase during lactation, whereas the intensity of the 34- and 24-kD bands declined. No significant trend was observed in the expression of the 28-kD IGFBP.

the intensity of each of the IGFBP bands was normalized by the $d-1$ postpartum sample for each sow. The intensities of the 43 - and $39-\mathrm{kD}$ bands tended to increase during

Table 3. Densitometric analysis of serum IGFBP throughout lactation*

\begin{tabular}{|c|c|c|c|c|}
\hline \multirow[b]{2}{*}{ Day } & \multicolumn{4}{|c|}{ IGFBP from Western ligand blot } \\
\hline & 43 and $39 \mathrm{kD} \dagger$ & $34 \mathrm{kD}$ & $28 \mathrm{kD}$ & $24 \mathrm{kD}$ \\
\hline 1 & $100 \neq$ & $1(x)^{2}$ & $100^{s}$ & $100)^{s}$ \\
\hline 2 & $144 \pm 41^{a h}$ & $80 \pm 33^{a h}$ & $165 \pm 95^{a}$ & $109 \pm 77^{a}$ \\
\hline 3 & $155 \pm 56^{a b}$ & $77 \pm 41^{u h}$ & $148 \pm 89^{2}$ & $80 \pm 18^{a}$ \\
\hline 4 & $176 \pm 69^{b}$ & $71 \pm 35^{a b}$ & $151 \pm 125^{a}$ & $56 \pm 12^{h}$ \\
\hline 7 & $182 \pm 85^{h}$ & $78 \pm 43^{a h}$ & $113 \pm 44^{a}$ & $58 \pm 22^{b}$ \\
\hline 10 & $166 \pm 98^{u h}$ & $67 \pm 43^{h}$ & $147 \pm 77^{a}$ & $48 \pm 10^{h}$ \\
\hline 14 & $211 \pm 93^{b}$ & $77 \pm 40^{x h}$ & $98 \pm 61^{a}$ & $41 \pm 35^{b}$ \\
\hline 18 & $174 \pm 148^{a b}$ & $73 \pm 22^{a b}$ & $88 \pm 26^{a}$ & $21 \pm 10^{b}$ \\
\hline 21 & $195 \pm 87^{h}$ & $78 \pm 27^{a b}$ & $79 \pm 13^{a}$ & $19 \pm 17^{h}$ \\
\hline 24 & $209 \pm 103^{h}$ & $90 \pm 49^{a h}$ & $127 \pm 67^{a}$ & $24 \pm 24^{b}$ \\
\hline 28 & $261 \pm 127 b^{h}$ & $73 \pm 43^{a b}$ & $173 \pm 140^{\mu}$ & $71 \pm 24^{u h}$ \\
\hline
\end{tabular}

* Mean \pm SD. d 1-24, $n=4 ;$ d $28, n=3$. Different letter superscripts indicate differences at $p \leq 0.05$.

+ The intensities of the 43- and 39-kD bands were summed.

$\ddagger$ Data for each sow were normalized by the intensity of the IGFBP band on $d 1$ of lactation. 
lactation and were significantly greater than $d-1$ postpartum intensities on $\mathrm{d} 4,7,14$, and $21-28$ postpartum. The intensity of the $34-\mathrm{kD}$ band averaged $70 \%$ of the concentrations observed on $\mathrm{d} 1$ postpartum but was only significantly lower on d 10 of lactation. The amount of the $28-\mathrm{kD}$ band in serum varied during lactation and was not significantly different from $\mathrm{d} 1$ at any other time during lactation. The intensity of the $24-\mathrm{kD}$ band showed a marked decline as lactation progressed and was significantly lower than $d-1$ values after $d 3$ postpartum $(p \leq 0.05)$.

Rotofor separation and Western ligand blotting of serum and milk IGFBP. Rotofor separations of d-4 postpartum porcine serum and milk samples are shown in Figures 2 and 3, respectively. Each figure shows duplicate gels: one was stained with Coomassie blue (panel $A$ ) and one was ligand blotted with $\left[{ }^{125} \mathrm{I}\right] \mathrm{IGF}$ (panel $B$ ). In serum, the 43and 39-kD IGFBP focused between $\mathrm{pH} 5.3$ and 6.5, whereas the lower molecular mass $\operatorname{IGFBP}(34,28$, and 24 kD) focused above pH 6.5 (Fig. 2B). The 43- and 39-kD bands (IGFBP-3) focused in the same fractions as serum albumin (Fig. 2A). IGFBP-2 (34 kD) and IGFBP-1 (28 kD) focused primarily in fractions between $\mathrm{pH} 6.5$ and 7.5, whereas the 24-kD band was fairly evenly distributed in fractions between $\mathrm{pH} 6.5$ and 9.6. Rotofor separations of serum from d 14 and 24 postpartum showed similar IGFBP abundance and separation profiles (data not shown).

Five IGFBP with $M_{r}$ similar to those in serum were observed in porcine milk (d 4 postpartum) (Fig. $3 B$ ). However, the relative amounts of the IGFBP bands in serum and milk were not identical. Relative to serum IGFBP, the 24-kD band was less prevalent in milk than in serum, whereas the $28-\mathrm{kD}$ band was present in greater amounts in milk than in serum. Several differences were noted in the Rotofor separations of porcine serum and milk IGFBP. In general, milk IGFBP focused more closely together (pH 6.6 to 7.8) than serum IGFBP $(\mathrm{pH}$ 5.3 to 9.6 ). In particular, the $43-$ and $39-\mathrm{kD}$ bands in milk focused at more neutral $\mathrm{pH}$ than the serum IGFBP of similar $\mathrm{M}_{\mathrm{r}}$. In addition, the $28-\mathrm{kD}$ band was apparent in neutral to basic fractions ( $\mathrm{pH} \mathrm{7.2-7.8)} \mathrm{and} \mathrm{in} \mathrm{acidic} \mathrm{frac-}$ tions ( $\mathrm{pH} 4.7-5.5$ ), cofocusing with casein (Fig. 3A). IGFBP were barely detectable on Rotofor separations of milk samples from d 14 and 24 postpartum (data not shown).

Milk IGF binding activity throughout lactation. The results of the charcoal binding assay are shown in Figure 4. Total $\left[{ }^{125}\right.$ I]IGF binding capacity was measured using IGFBP that had been stripped of endogenous IGF by Sephadex G-50 formic acid column chromatography. The assay was performed using $100 \mu \mathrm{L}$ of samples of the IGFBP fraction (diluted 1:40); therefore, the total binding activity was measured in the equivalent of $2.5 \mu \mathrm{L}$ of the original milk sample. The assay was checked for linearity using the milk sample that showed the highest total binding activity $(55 \%$ specific binding). The assay was linear $(r=0.98)$ between 10 - and $100-\mu \mathrm{L}$ sample size, representing 19 to $55 \%$ specific binding of the $\left.{ }^{125} \mathrm{I}\right] \mathrm{IGF}-\mathrm{I}$. IGF binding activity (mean \pm SD) decreased in porcine milk during lactation from 28 $\pm 8 \%$ on $\mathrm{d} 1$ to $7 \pm 1.2 \%$ on $\mathrm{d} 28$ postpartum. However, unlike IGF-I and -II, which were highest in prepartum secretions and colostrum, [ $\left.{ }^{125} \mathrm{I}\right] \mathrm{IGF}$ binding activity rose for the first $2 \mathrm{~d}$ postpartum, peaking on $\mathrm{d} 3$ and 4 postpartum $(44 \pm 9.9 \%)$ before declining. Prepartum secretions, which contained nearly twice as much IGF-I and - II as the $d-1$ colostrum, bound only $17 \pm 4.5 \%$ of the $\left[{ }^{125} \mathrm{I}\right] \mathrm{IGF}-\mathrm{I}$. Milk IGF binding activity was only weakly correlated with milk IGF-I $(r=0.30, p=0.05)$ and was not significantly correlated with milk IGF-II concentration $(r=0.26, p=0.09)$.

\section{DISCUSSION}

IGF undoubtedly contribute to the growth-promoting activity of milk $(3,8,21)$ and thus may play a role in the marked intestinal growth observed in suckling neonatal animals (22). IGF-I has been previously reported in human milk $(1,23,24)$ and the milk of rats (2), pigs (3), goats (4), and cows (5). In addition, IGF-II has been measured in human (1), rat (2), ovine (25), and bovine (26) milk. This study is the first to report IGF-II concentrations in porcine milk.

IGF-II was found to be the predominant IGF in porcine serum, prepartum mammary secretions, colostrum, and milk through $\mathrm{d} 7$ postpartum. Concentrations of IGF-II in porcine milk through $\mathrm{d} 7$ postpartum were approximately 2 -fold higher than IGF-I. On d 10 and throughout the rest of lactation, both IGF-I and -II concentrations were significantly lower than colostral concentrations and were of approximately equal concentration $(10-30 \mu \mathrm{g} / \mathrm{L}$ or $1-3 \mathrm{nM})$. IGF-I concentrations of 30 to $140 \mu \mathrm{g} / \mathrm{L}$ (4 to $17.8 \mathrm{nM}$ ) in porcine prepartum mammary secretions and colostrum were higher than those reported in human $(7-27 \mu \mathrm{g} / \mathrm{L})(1,23$, 24) or rat colostrum $(25-30 \mu \mathrm{g} / \mathrm{L})(2)$, but were below concentrations in bovine colostrum $(100-600 \mu \mathrm{g} / \mathrm{L})(5)$. Our IGF-I concentrations were also somewhat lower than those reported for porcine colostrum by Simmen et al. $(3,9)$. They reported colostral IGF-I concentrations in the range of $67-357 \mu \mathrm{g} / \mathrm{L} \mathrm{(3)} \mathrm{and} 584-1271 \mu \mathrm{g} / \mathrm{L}$ (9). Variation between the studies may be a reflection of breed differences or the fact that their samples were collected within $12 \mathrm{~h}$ postpartum, whereas our first samples may have been obtained $>12 \mathrm{~h}$ postpartum. IGF-I and -II concentrations in porcine milk after $d 7$ postpartum were between 10 and $30 \mu \mathrm{g} / \mathrm{L}$, which is comparable to concentrations reported for other species $(1-5,9,23-25)$.

IGF in milk may arise from de novo mammary synthesis or by transfer from the maternal circulation. IGF-I $(27,28)$ and IGF-II $(28)$ mRNA have been reported in porcine mammary tissue; however, the expression is low, suggesting that maternal serum is the likely source of milk IGF. The presence of both type I and type II IGF 


\section{A) Commassie Blue}

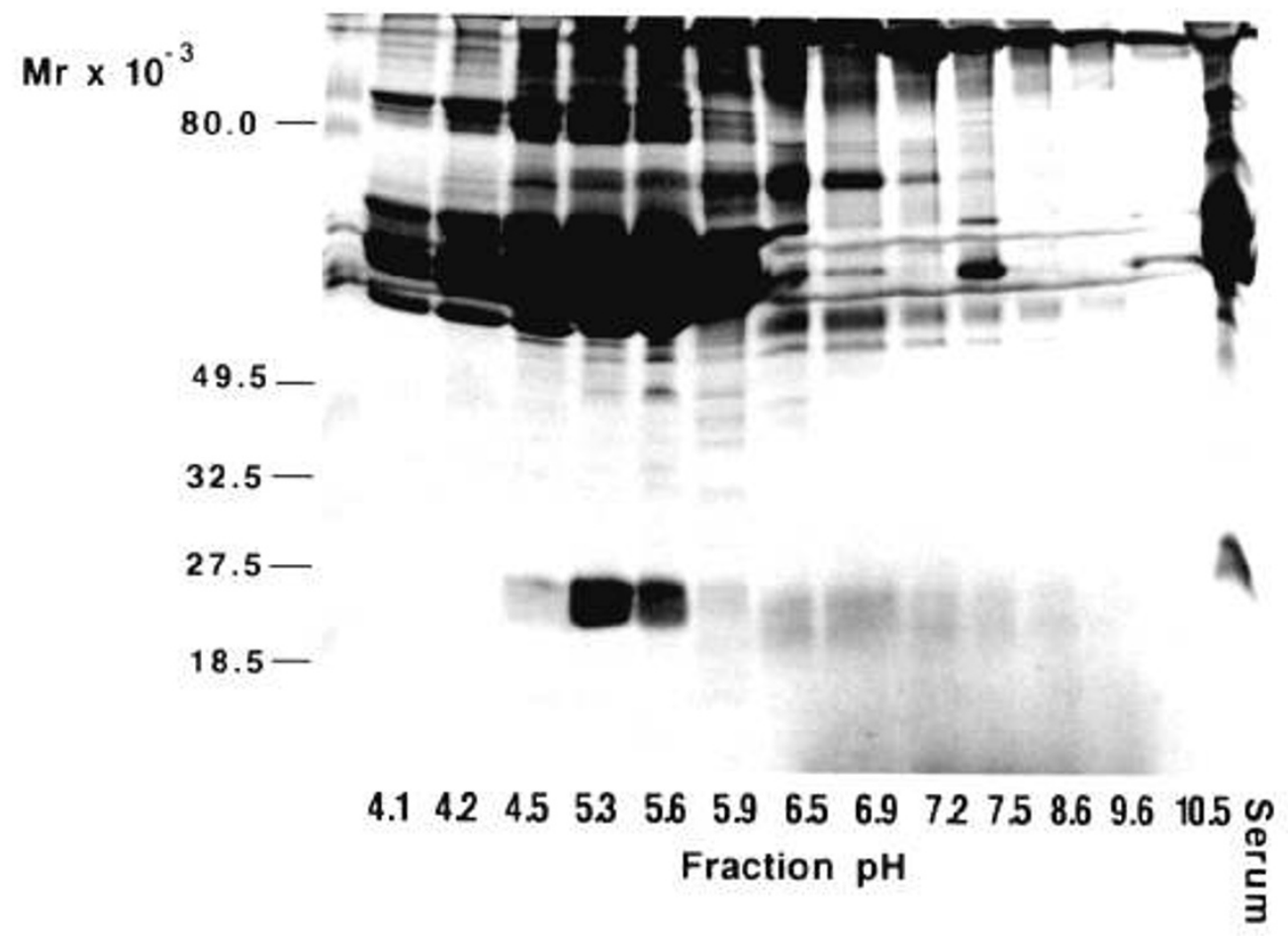

\section{B) Western Ligand Blot}

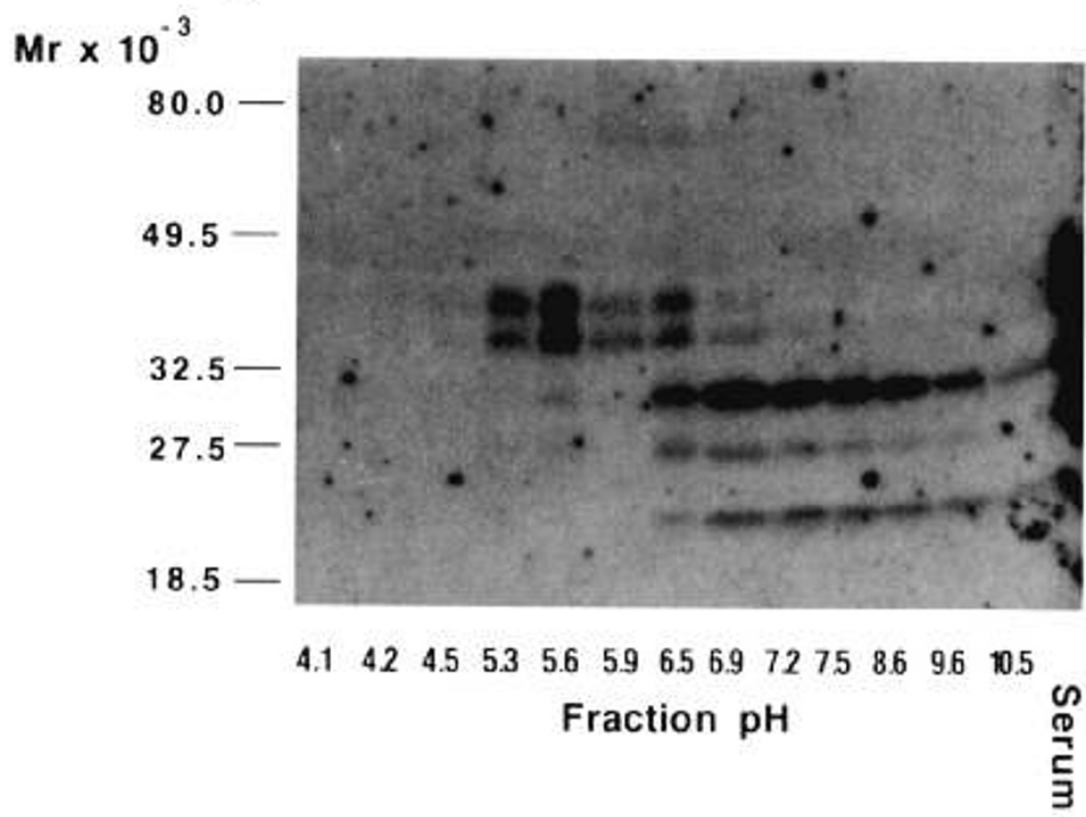

Figure 2. Rotofor separation of porcine serum from d 4 postpartum. A serum sample $(500 \mu \mathrm{L})$ was separated by isoelectric focusing on a Rotofor apparatus into 20 fractions over a pH gradient of 3 to 10 . Fractions 8-20 were separated on duplicate SDS-PAGE gels. One gel was stained with Coomassie blue to show the protein separation $(A)$. The other gel was transferred to nitrocellulose, Western ligand blotted using [ ${ }^{125} \mathrm{I} / \mathrm{IGF}-\mathrm{I}$, and exposed to film for $10 \mathrm{~d}(B)$. Bands with apparent $\mathrm{M}_{\mathrm{r}}$ of $43,3934,28$, and $24 \mathrm{kD}$ were visualized.

receptors $(28)$ in porcine mammary tissue could allow for receptor-mediated translocation from the maternal circulation into milk.

Recent studies by Prosser et al. $(25,29)$ have provided direct evidence that serum is the primary source of milk IGF. Close-arterial infusions of $\left[{ }^{125}\right.$ I]IGF-I (29) or $\left[{ }^{125}\right.$ I]IGF-II (25) into one mammary gland of lactating goats demonstrated that both peptides are transported from the maternal circulation into milk. However, it seems that either the method of transport or the saturability of the pathway differs for the two peptides. The addition of unlabeled IGF-I to the infusate reduced the specific activity of $\left[{ }^{125}\right.$ I] IGF-I in milk, suggesting that the IGF-I transport mechanism is competitive and saturable 


\section{A) Commassie Blue}

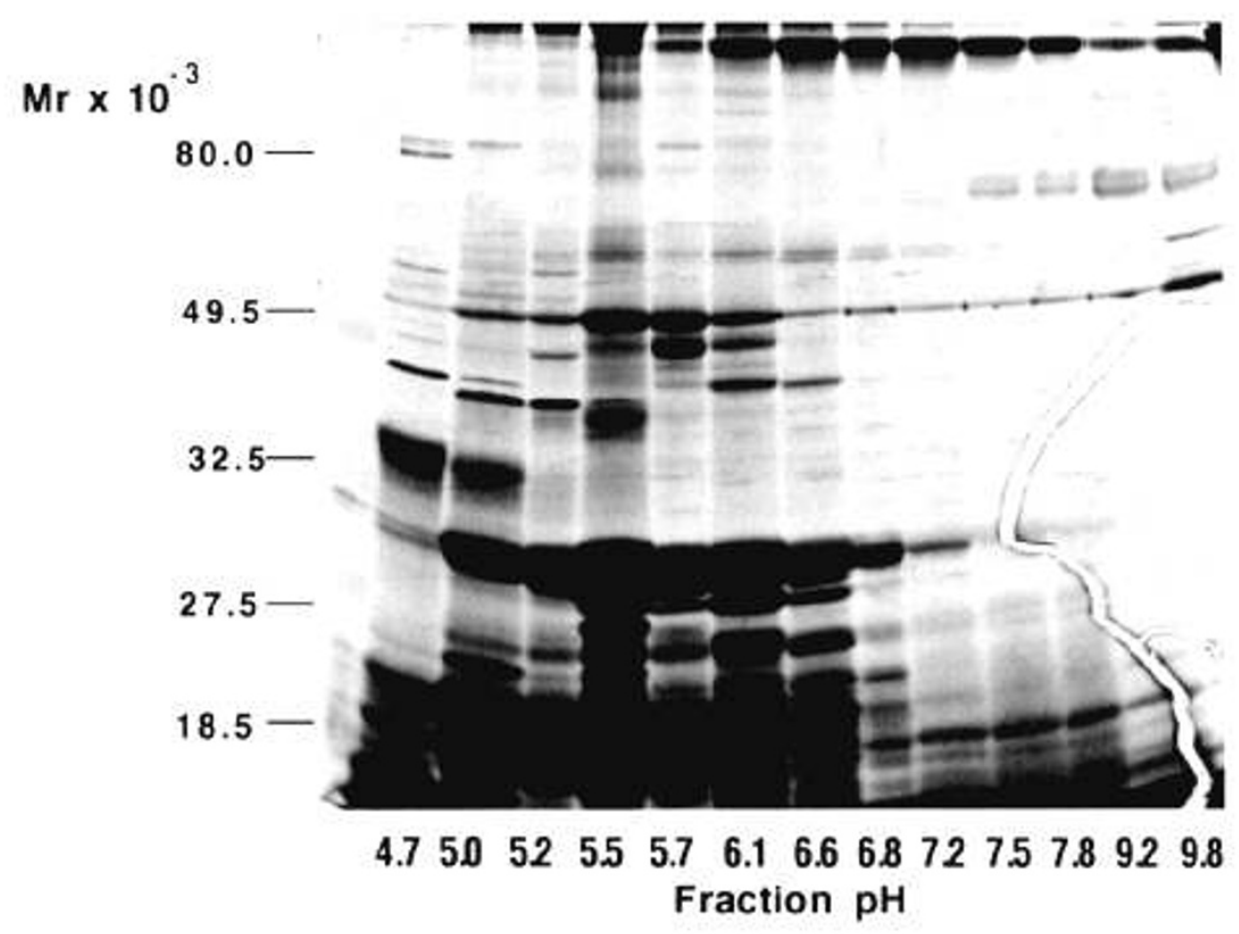

B) Western Ligand Blot

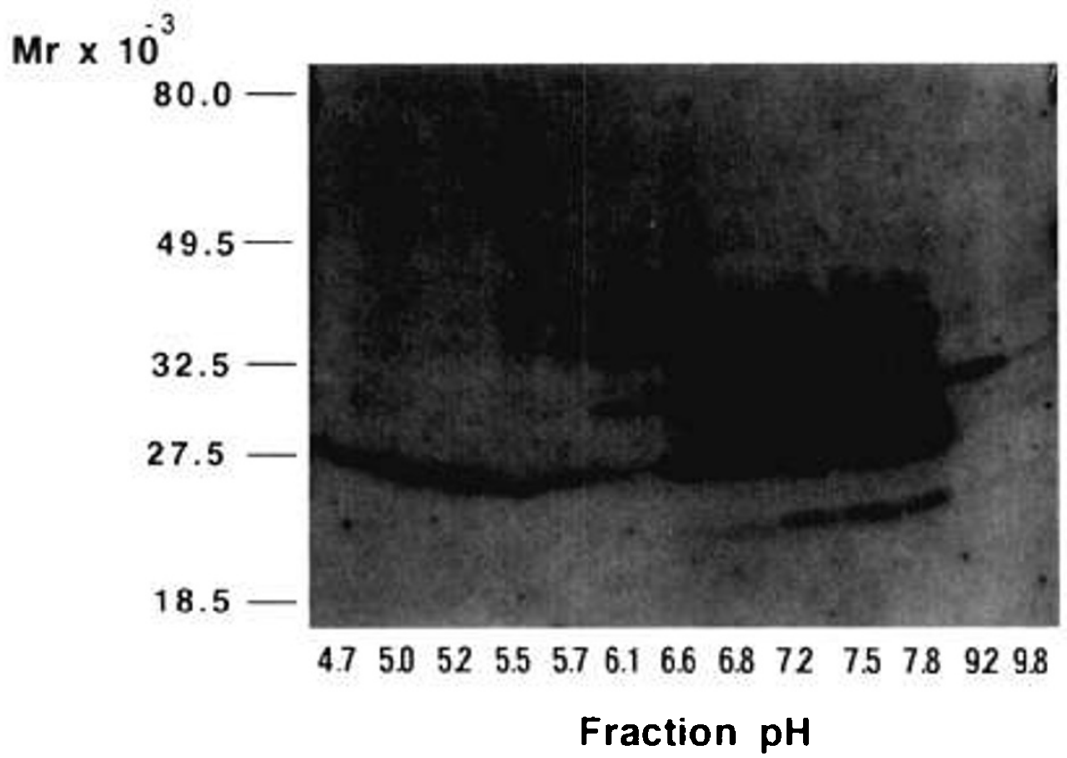

Figure 3. Rotofor separation of porcine milk from d 4 postpartum. A serum sample $(1.0 \mathrm{~mL})$ was separated by isoelectric focusing on a Rotofor apparatus into 20 fractions over a pH gradient of 3 to 10 . Fractions 8-20 were separated on duplicate SDS-PAGE gels. One gel was stained with Coomassie blue to show the protein separation $(A)$. The other gel was transferred to nitrocellulose, Western ligand blotted using [ $\left.{ }^{125} \mathrm{I}\right] \mathrm{IGF}-\mathrm{I}$, and exposed to film for $10 \mathrm{~d}(B)$. Bands with apparent $\mathrm{M}_{\mathrm{r}}$ of $43,39,34,28$, and $24 \mathrm{kD}$ were visualized.

(29). In contrast, the presence of unlabeled IGF-II in the infusate did not lower the specific activity of [ ${ }^{125}$ I]IGF-II in milk (25). They concluded that IGF-I is transported into milk via a transcellular rather than paracellular route, whereas IGF-II is transported nonspecifically, potentially within pinocytotic vesicles. The inverse relationship between pig serum and milk IGF-II concentrations $(r=-0.46, p=0.002)$ supports the hypothesis that milk IGF-II is derived from the maternal circulation. In early lactation, when milk IGF-II content is at its highest, serum IGF-II concentrations are depressed. As milk IGF-II concentrations decline through lactation, a concomitant rise in circulating IGF-II concentrations is observed. The additional increase in both serum IGF-I and -II concentrations postweaning also supports this hypothesis (Table 2). 


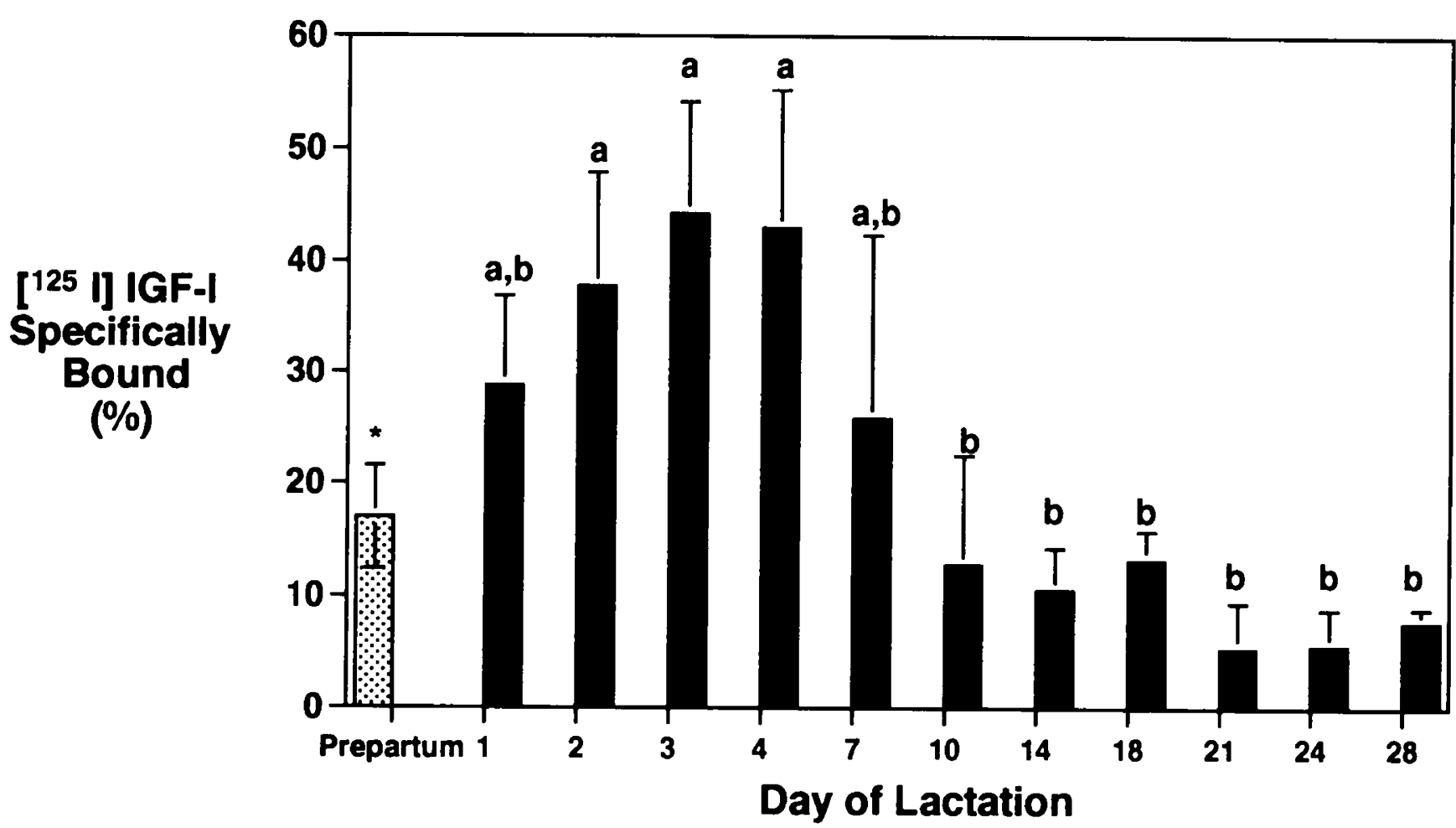

Figure 4. Pig milk IGFBP binding activity throughout lactation. Milk IGFBP activity (mean \pm SD) of prepartum mammary secretions and sow colostrum and milk from d 1 to 28 of lactation was assessed by the charcoal method. Milk [ ${ }^{125}$ I]IGF-I binding activity rose until d 4 postpartum, then declined through $\mathrm{d} 28$ of lactation.

Four of the six known IGFBP (IGFBP-1 through -4) have been reported in milk. Initial studies characterized milk IGF binding activity as high molecular mass (150 $\mathrm{kD}$ ) or low molecular mass (40 kD) IGFBP fractions by incubating milk with $\left[{ }^{125} \mathrm{I}\right] \mathrm{IGF}$ and separating the labeled peaks by gel filtration column chromatography. The $150-\mathrm{kD}$ peak is the circulating molecular mass of serum IGFBP-3 and is composed of a ternary complex of IGFBP-3, IGF peptide, and an $85-\mathrm{kD}$ protein known as the the acid labile subunit (11). Using the gel filtration method, the $150-\mathrm{kD}$ peak (IGFBP-3) and the $40-\mathrm{kD}$ binding peak were demonstrated in human $(23,24)$, rat $(30)$, and porcine (3) milk. Recent studies using Western ligand blotting have characterized which IGFBP contribute to the $40-\mathrm{kD}$ peak in milk. The low molecular mass IGFBP in milk vary by species but include IGFBP-2 $(1,2,30)$, IGFBP-1 (31), and IGFBP-4 $(2,30)$.

In this study, the porcine milk IGFBP were characterized by isoelectric focusing and Western ligand blotting. Five IGFBP bands with apparent $M_{r}$ of $43,39,34,28$, and $24 \mathrm{kD}$ were detected in porcine milk. Relative to the abundance of the other IGFBP, the 24-kD IGFBP in milk was less abundant than in serum, which is similar to what we have observed in the rat (2). The IGFBP in porcine milk focused primarily at neutral to slightly basic $\mathrm{pH}$ with the exception of the $28-\mathrm{kD}$ band, which was also present in acidic fractions ( $\mathrm{pH} 4.7-5.5)$. If the $28-\mathrm{kD}$ band is IGFBP-1, the $\mathrm{pH}$ change may be caused by posttranslational modifications, inasmuch as IGFBP-1 has been shown to be phosphorylated in porcine serum (32). How- ever, the $28-\mathrm{kD}$ band in milk may not be IGFBP-1, because it was not recognized by an antibody to IGFBP-1 (R. H. McCusker, personal communication). Additional purification and characterization of the IGFBP from each fraction will determine whether posttranslational modifications are responsible for the apparent pI differences between milk and serum IGFBP or whether the bands represent different IGFBP.

Longitudinal changes in milk total IGF binding activity were measured by charcoal binding assay. Interestingly, although IGF peptide concentrations were highest in prepartum secretions through d 2 of lactation, peak milk IGF binding activity was not observed until d 4 postpartum. A potential explanation for the temporal differences in peak IGF peptide and IGFBP concentrations may be that milk IGF and IGFBP arise from different sources. IGF-I and -II arise primarily from the maternal circulation $(25,29)$ and are concentrated in the mammary gland in late gestation $(5,28)$. The IGF that has been sequestered before parturition is released into the milk at the onset of lactogenesis, resulting in very high milk concentrations in early milk. In contrast, IGFBP can be transported into milk from the maternal circulation or can be synthesized de novo within the lactating mammary gland (28). IGFBP-2 and -3 mRNA has been demonstrated in pig mammary gland (28). On d 4 postpartum, mammary IGFBP- 2 mRNA concentration was 2 -fold higher than at $\mathrm{d} 30$ of gestation but was equal to the concentration observed on $d 112$ of pregnancy (28). Because of the lack of longitudinal measure- 
ments of IGFBP mRNA expression in lactating pig mammary glands, we cannot determine whether our "peak" IGF binding activity correlates with peak mammary IGFBP expression.

Ingestion of colostrum by the piglet causes a marked increase in intestinal mass and functional maturation that is thought to be due in part to the presence of milk-borne growth factors (22). The presence of type I and type II IGF receptors in the intestinal epithelium of pigs (8) suggests that IGF in milk may play a role. Several recent studies have investigated the role of IGF in the neonate (33-35). When [ $\left.{ }^{125} \mathrm{I}\right] \mathrm{IGF}-\mathrm{I}$ was orally administered to suckling rats, approximately $78 \%$ of the dose was retained by the animals, predominantly in the stomach and intestinal lining (33). Studies in neonatal calves have demonstrated that ${ }^{125}$ I]IGF-I added to bovine colostrum was absorbed into the blood (34). In addition, consumption of a milk replacer supplemented with IGF-I resulted in lower circulating insulin and higher circulating prolactin concentrations compared with those in calves ingesting unsupplemented milk replacers (35). Taken together, these results suggest that exogenous IGF is able to at least partially survive digestion, interact with the gastrointestinal tract, be absorbed into the blood, and affect the secretion of other hormones.

In summary, both IGF-I and -II are present in porcine milk. IGF-II concentration $(10-40 \mathrm{nM})$ is approximately 2-fold higher than IGF-I concentration (4-17 $\mathrm{nM})$ in prepartum secretions and colostrum. In mature milk, IGF-I and -II concentrations are approximately equivalent at $1-3 \mathrm{nM} / \mathrm{L}$. It is important to note, however, that the $\mathrm{kD}$ for the type I receptor in the piglet gastrointestinal tract $(\approx 1 \mathrm{nM})$ is within the range of normal milk IGF concentrations $(8)$. In addition, the average milk intake over lactation is $800 \mathrm{~mL} / \mathrm{d}(36)$, resulting in ingestion of approximately $9 \mu \mathrm{g} / \mathrm{d}$ of IGF-I and $10 \mu \mathrm{g} / \mathrm{d}$ of IGF-II between $\mathrm{d} 7$ and 28 postpartum. Our future studies will focus on whether IGF ingested at these concentrations are of physiologic importance in neonatal growth and gastrointestinal development.

Acknowledgments. The authors thank Marcia Monaco and Xiaohui Zhao for their assistance with IGF-I and -II analyses.

\section{REFERENCES}

1. Donovan SM, Hintz RL, Rosenfeld RG 1991 Insulin-like growth factors I and $\mathrm{II}$ and their binding proteins in human milk: effect of heat treatment on IGF and IGF binding protein stability. J Pediatr Gastroenterol Nutr 13:242253

2. Donovan SM, Hintz RL, Wilson DM, Rosenfeld RG 199 ! Insulin-like growth factors I and II and their binding proteins in rat milk. Pediatr Res 29:50-55

3. Simmen FA, Simmen RCM, Reihnart G 1988 Maternal and neonatal somatomedin-C/insulin-like growth factor-I (IGF-I) and IGF binding proteins during early lactation in the pig. Dev Biol 130:16-20

4. Prosser CG, Fleet IR, Corps AN, Froesch ER, Heap RB 1990) Increase in milk secretion and mammary blood flow by intra-arterial infusion of insulinlike growth factor-I into the mammary gland of the goat. J Endocrinol 126:437-443

5. Campbell PG, Baumrucker CR 1989 Insulin-like growth factor-I and its association with binding protein in bovine milk. J Endocrinol 120:21-29
6. Shamay A, Cohen N, Niwa M, Gertler A 1988 Effects of insulin-like growth factor I on deoxyribonucleic acid synthesis and galactopoiesis in bovine undifferentiated and lactating mammary tissue. Endocrinology 123:804-809

7. Davis SR, Gluckman PD, Hart IC. Henderson HV 1987 Effects of injecting growth hormone or thyroxine on milk production and blood plasma concentration of insulin-like growth factors $I$ and $I I$ in dairy cows. J Endocrinol $114: 17-24$

8. Schober DA, Simmen FA, Hadsell DL, Baumrucker (R 199) Perinatal expression of type I IGF receptors in porcine small intestine. Endocrinology 126:1125-1132

9. Simmen FA, Whang KY, Simmen RCM, Peterson GA, Bishop MD, Irvin KM 1990 Lactational variation and relationship to postnatal growth of insulin-like growth factor-I in mammary secretions from genetically diverse sows. Domestic Animal Endocrinol 7:199-206

10. Shimasaki S, Ling NL 1991 Identification and molecular characterization of insulin-like growth factor binding proteins (IGFBP-1, -2, -3, -4, -5, and -6). Prog Growth Factor Res 3:243-266

11. Walton PE, Baxter RC, Burleigh BD, Etherton TD 1989 Purification of the serum acid-stable insulin-like growth factor binding protein from the pig (Sis scrofa). Comp Biochem Physiol 92B:561-567

12. Walton PE, Gopinath R. Burleigh BD. Etherton TD 1989 Administration of recombinant human IGF-I into pigs: determination of circulating half lives and chromatographic profiles. Horm Res 31:138-142

13. McCusker RH, Busby WH, Dehoff MH, Comacho-Hubner C, Clemmons DH 1991 Insulin-like growth factor (IGF) binding to cell monolayers is directly modulated by the addition of IGF-binding proteins. Endocrinology 129:939949

14. Peterson GL 1977 A simplification of the protein assay method of Lowry et al. Anal Biochem 83:346-356

15. Horner JM, Hintz RL 1982 Comparison of 125-I-SM-A and 125-I-SM-C125] SM-A and ${ }^{125} \mathrm{I}-\mathrm{SM}-\mathrm{C}$ radioreceptor assays for somatomedin peptide content in whole and acid chromatographed plasma. J Clin Endocrinol Metab 47:1287-1295

16. Hossenlopp P. Seurin D, Segovia-Quinson B, Hardouin S, Binoux M 1986 Analysis of serum insulin-like growth factor binding proteins using western blotting: use of the method for titration of the binding proteins and compet itive binding studies. Anal Biochem 154:138-143

17. Laemmli V 1970 Cleavage of structural proteins during the assembly of the head of bacteriophage T4. Nature 227:680-685

18. Lee CY, Bazer FW, Etherton TD, Simmen FA 1991 Ontogeny of insulin-like growth factors (IGF-I and IGF-II) and IGF-binding proteins in porcine serum during fetal and postnatal development. Endocrinology 128:2336-2344

19. McCusker RH, Cohick WS, Busby WH, Clemmons DR 1991 Evaluation of the developmental and nutritional changes in porcine insulin-like growth factor binding protein-1 and protein-2 serum levels by immunoassay. Endocrinology 129:2631-26.38

70. Ceda GP. Fielder PJ, Henzel WJ, Louie A, Donovan SM, Hoffman AR. Rosenfeld RG 1991 Differential effects of IGF-I and IGF-II on the expression of IGF binding proteins (IGFBPs) in a rat neuroblastoma cell line: isolation and characterization of two forms of IGFBP-4. Endocrinology 128:2815-2824

21. Simmen FA, Simmen RCM, Letcher LR, Schober, DA. Ko Y 1989 IGFs in pregnancy: developmental expression in uterus and mammary gland and paracrine actions during embryonic and neonatal growth. In: LeRoith D, Raizada MK (eds) Molecular and Cellular Biology of Insulin-Like Growth Factors and Their Receptors. Plenum Press, New York, pp 195-208

22. Widdowson EM, Colombo VE, Artavanis PA 1976 Changes in the organs of pigs in response to feeding for the first $24 \mathrm{~h}$ after birth. II. The digestive tract. Biol Neonate 28:272-281

23. Baxter RC, Zaltsman Z, Turtle JR 1984 Immunoreactive somatomedin-C/ insulin-like growth factor 1 and its binding protein in human milk. J Clin Endocrinol Metab 58:955-959

24. Corps AN, Brown KD, Rees LH, Carr J. Prosser CG 1988 The insulin-like growth factor I content in human milk increases between early and full lactation. J Clin Endocrinol Metab 67:25-29

25. Prosser CG, Fleet IR 1992 Secretion of insulin-like growth factor II into milk. Biochem Biophys Res Commun 183:1230-1237

26. Vega JR, Gibson CA. Skaar TC, Hadsell DL, Baumrucker CR 1991 Insulinlike growth factor (IGF) and IGF binding proteins in serum and mammary secretions during the dry period and early lactation in dairy cows. J Anim Sci $69: 2538-2547$

27. Tavakkol A, Simmen FA, Simmen RCM 1988 Porcine insulin-like growth factor-I (pIGF-I): complementary deoxyribonucleic acid cloning and uterine expression of messenger ribonucleic acid encoding evolutionarily conserved IGF-I peptides. Mol Endoctinol 2:674-681

28. Lee CY, Bazer FW, Simmen FA 1993 Expression of components of the insulin-like growth factor system in pig mammary glands and serum during pregnancy and pseudopregnancy: effects of oestrogen. J Endocrinol 137:473483

29. Prosser CG, Davis AJ, Fleet IR, Rees LH, Heap RB 1987 Mechanism of transfer of IGF-I into milk. J Endocrinol 131:459-466

30. Donovan SM, Hintz RL, Rosenfeld RG 1992 Sources of insulin-like growth factor-I and insulin-like growth factor binding protein in rat milk. In: Picciano MR. Lönnerdal B (eds) Mechanisms Regulating Lactation and Infant Nutrient Utilization. Wiley-Liss, New York, pp 377-382 
31. Skarr TC, Vega JR, Pyke SN, Baumrucker CR 1991 Changes in insulin-like growth factor-binding proteins in bovine mammary secretions associated with pregnancy and parturition. J Endocrinol 131:127-133

32. McCusker RH, Jones JI, Clemmons DR 1992 Insulin-like growth factor (IGF) binding protein-1 (IGFBP-1) is phosphorylated in porcine serum. J Anim Sci 70:213(abstr)

33. Phillips AF, Rao R, McCracken D, Koldovsky O 199) Presence of insulin-like growth factor-1 ( $\mathrm{GGF}-1)$ in rat milk and the absorption of IGF-1 by the suckling rat. Pediatr Res 27:49A(abstr)
34. Baumrucker CR, Hadsell DL, Skatar TC. Camphell PG, Blum JW 1992 Insulin-like growth factors (IGFs) and IGF binding proteins in mammary secretions: origins and implications in neonatal physiology. In: Picciano MR. Lonnerdal $B$ (eds) Mechanisms Regulating Lactation and Infant Nutrient Utilization. Wiley-Liss, New York, pp 285-308

35. Baumrucker CR, Blum JW 1993 Secretion of insulin-like growth factors in milk and their effect on the neonate. Livestock Prod Sci 35:49-72

36. Elsley FWH 1970 Nutrition and lactation in the sow. In: Falconer IR (ed) Lactation. Butferworths, Iondon, pp $393-411$ 